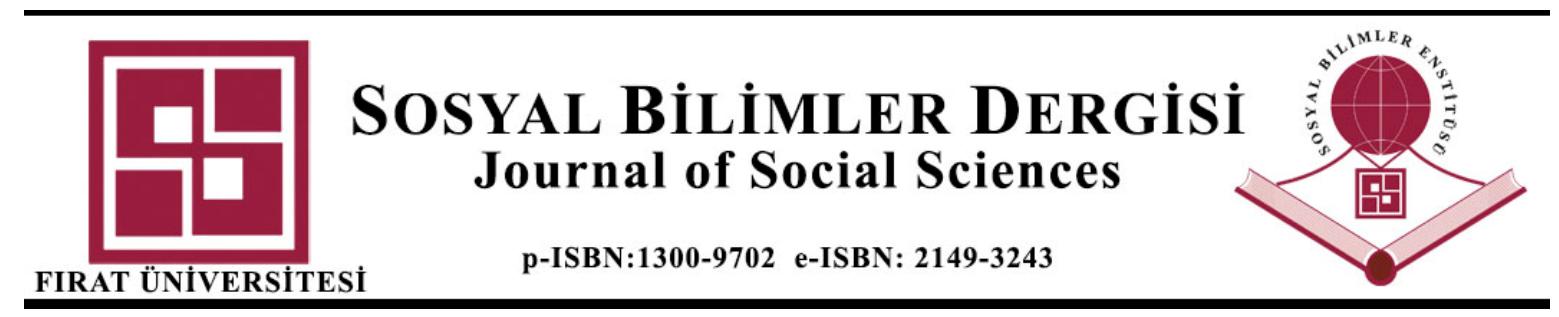

\title{
GELENEKSEL BÜROKRASİNIN İLK İZLERİ: MALATYA ARSLANTEPE
}

First Traces of Traditional Bureaucracy: Malatya Arslantepe

\section{Hasan YILMAZ ${ }^{1}$}

${ }^{l}$ Dr. Öğr. Üyesi, İn̈nü Üniversitesi, İktisadi ve İdari Bilimler Fakültesi, Siyaset Bilimi ve Kamu Yönetimi Bölümü, Malatya,Türkiye,hyilmaz@inonu.edu.tr, orcid.org/0000-0001-9212-8084

\section{MakaleBilgisi \\ Geliş/Received: \\ 31.03.2021 \\ Kabul/Accepted: \\ 03.05.2021}

DOI:

10.18069/firatsbed.907497

AnahtarKelimeler Bürokrasi, Geleneksel bürokrasi, Malatya, Arslantepe,

\section{ÖZ}

Türkiye son yıllarda arkeolojik çalışmalarda önemli buluntulara ev sahipliği yapmaktadır. Malatya'da Arslantepe Höyüğ̈ü bu konudaki önemli arkeolojik keşiflerden biridir. Tarihin farklı dönemlerine ait izler taşıyan Arslantepe'de ilk buluntular, M.Ö. 6000'li yılara kadar uzanmaktadır ve bu tarihin daha eskilere uzanacağı düşünülmektedir. Çünkü hali hazırda arkeolojik çalışmalar höyüğün bir başka alanında devam etmektedir. Malatya il merkezine $7 \mathrm{~km}$. uzaklıkta Battalgazi ilçesinde yer alan höyük, yerden 30 metre yükseklikte ve kesintisiz bir yerleşim katmanından oluşmuştur. Arkeolojik kazılarda; saray tarzında bir yapının varlığı, ekonomik işler için geliştirilen uygulama örnekleri (depolama, cretula ve mühürler), askeri hiyerarşik yapıyı ifade eden metal kılıç ve eşyalar, sınıflı bir toplum yapısının varlığı ve gıda ambarlarının depolama ve dağıtma gibi işlevlerinin olması geleneksel bürokrasinin varlığını akla getirmektedir. Ayrıca saray duvarlarında seçkin sınıfa ait olduğu düşünülen kabartma ve figürlerin, kral mezarının, sarayda kabul alanı gibi buluntuların siyasi ve idari yapıda seçkin bir sınıfın varlığına işaret edebileceği düşünülmektedir. Klasik bilgiler bürokrasinin tarihi geçmişinin Eski Çin, Misır medeniyetlerine dayandığını belirtmektedir. Oysa her iki medeniyetten daha eski bir tarihe dayanan Arslantepe'nin bürokratik yapısıyla literatürde ilk örnekler arasında yer alması gerektiği düşünülmektedir. Ayrıca bu çalışmada, bürokrasinin tarihi kökeninin genel kabul görmüş bilgilerden daha eski bir tarihe dayandığı ileri sürülmektedir.
Keywords Bureaucracy, Traditional bureaucracy, Malatya, Arslantepe

\begin{abstract}
In recent years Turkey is home to the most important finds in archaeological work. Arslantepe Mound in Malatya is one of the important archaeological discoveries on this subject. The first find in Arslantepe, which bear traces of different periods of history, BC. It goes back to the $6000 \mathrm{~s}$ and it is thought that this date will extend back to earlier times. Because archaeological studies are currently ongoing in another area of the mound. Located in Battalgazi district, 7 kilometres from Malatya city centre, the mound is 30 meters above the ground and consists of an uninterrupted settlement layer. In archaeological excavations; The existence of a palace-style structure, application examples developed for economic affairs (storage, cretula and seals), metal swords and items expressing the military hierarchical structure, the existence of a class social structure, and the functions such as storage and distribution of food warehouses suggest the existence of traditional bureaucracy. Besides, it is thought that the reliefs and figures thought to belong to the elite class on the palace walls, the king's tomb, and the findings such as the reception area in the palace may indicate the existence of an elite class in the political and administrative structure. Classical historical information states that the historical background of bureaucracy is based on Ancient Chinese and Egyptian civilizations. However, it is thought that Arslantepe, which is based on a history older than both civilizations, should be among the first examples in the literature with its bureaucratic structure. Also, this study suggests that the historical roots of bureaucracy are older than generally accepted information.
\end{abstract}

Atıf/Citation: YILMAZ, H. (2021). Geleneksel Bürokrasinin İlk İzleri: Malatya Arslantepe. Firat Üniversitesi Sosyal Bilimler Dergisi. 31, 2(795-806).

Sorumlu yazar/Corresponding autohor: Hasan YILMAZ, hyilmaz@inonu.edu.tr 


\section{Giriș}

Türkiye'de arkeolojik çalışmaların giderek yaygınlaştığı görülmektedir. Türkiye sınırları içerisinde M.Ö. 10.000 'li yıllara varan bulgular, Türkiye'nin kültür ve medeniyet tarihi açısından zengin bir ülke olduğuna işaret etmektedir. Bu durum farklı medeniyetlere ev sahipliği yapmış bir coğrafyada farklı öğreti ve inanç sistemlerinin varlı̆̆ını da göstermektedir. Bu bağlamda arkeolojik bulgular geçmiş toplumların sosyal, ekonomik ve siyasal yaşamından izleri gün yüzüne çıkarmakta ve gelecek nesillere aktarmaktadır.

Bürokrasi kavramı geleneksel ve modern olarak iki açıdan ele alınmaktadır. Birincisi tarihsel süreçte yöneten-yönetilen kavramlarından hareketle daha çok yönetsel bir eylem olarak geleneksel bürokrasi, ikincisi ise Weber' in bürokrasi modeli ile gelişen modern bürokrasi anlayışıdır. Özellikle ilk devletlerin oluşmasıyla birlikte iktidarı elinde bulunduran yapı ile toplum arasındaki ilişkilerin yapısal durumu önem kazanmış, birtakım işler belirli kurallara göre ve hiyerarşik bir düzende yapılmaya başlanmıştır. Bu anlamda geleneksel bürokrasi devlet idaresinin düzenli işleyişi ve kurallara bağlı bir yönetim anlayışına işaret etmektedir.

2014 yılında UNESCO Dünya Miras Geçici Listesi'ne alınan ve yakın zamanda asıl listeye girmesi beklenen Arslantepe'de arkeolojik çalışmalar devam etmektedir. Arslantepe'de kazı çalışmaları Roma La Sapienza Üniversitesi'nden Doç. Dr. Francesca Balossi Restelli'nin başkanlığını yaptığı bir ekip tarafından devam etmektedir. Kazı çalışmalarında yer alan ekiptekilerin birçoğu Arslantepe üzerinde uzmanlaşmışlardır. Kazı ekibinde yer alan akademisyenler farklı bilimsel çalışmalar ortaya koymuşlardır. Arslantepe ile ilgili başta kazı ekibinden hocalar olmak üzere farklı başlıklarda bilimsel çalışmalar yapılmış̧ır. Bu çalışma bürokrasinin tarihi kökeni ile ilgili bilgileri, arkeolojik verilerden yola çıarak farklı bir bakış açısıyle değerlendirmeyi hedeflemektedir.

\section{Yöntem ve Amaç}

Bu bölümde çalışmanın yöntemi ve amaçları hakkında detaylı bilgiler paylaşılmaktadır. Genel olarak çalışmanın yöntemi, amacı, sınırlılıkları ve araştırma soruları ele alınmaktadır. Çalışmanın genel hatları bu bölümde ifade edilirken, diğer yandan çalışmaya neden ihtiyaç duyulduğu hakkında kanaat oluşturması hedeflenmektedir.

\section{1. Çalışmanın Yöntemi}

Çalışma, sosyal bilimlerde tarihsel bir boyutu ele aldığı için tarihsel araştırma yöntemi kapsamında tarama (veriye ulaşma), tasnif (sınıflandırma), tahlil ( çözümleme), tenkit (eleştiri) ve terkip (sentez) aşamalarından oluşan yöntemle yapılmaktadır. Ayrıca tarihsel olayları derinlemesine araştırabilmek adına ayrı bir tarihsel karşılaş̧ırmalı yaklaşım modeline uygun olarak farklı bilimlerden yararlanılmış, başka yerdeki gerçekleri yeniden ortaya koymaya; nedenler, kanttlar, bağlamlar üzerinden kurgular üretilmek istenmiştir. Farklı bir tarihsel karşılaştırmalı yaklaşımında olaylar geniş bir şekilde eylemler, semboller üzerinden ele alınarak, toplumsal yaşamın belirli bir yönü üzerine odaklanma (Neuman, 2006: 609) ve buradaki bulgular üzerinden bir çıkarımda bulunma amacını taşımaktadır. Bu çalışmada Malatya ilinde yer alan Arslantepe Höyüğünde yapılan arkeolojik kazılar ve kazı sonucunda elde edilen bulgular incelenmektedir. İnceleme sonucu çıkan bulgular tartışma ve sonuç bölümünde değerlendirilmektedir.

\section{2. Çalışmanın Amacı}

Çalışmanın amacı; Malatya ilinde yer alan Arslantepe Höyüğü’nde yapılan kazı çalışmaları sonrasında ortaya çıkan bulgular üzerinde, bürokratik yapı çerçevesinde, bir tahlil ve çıkarım yapabilmektir. M.Ö. 6000'li yıllara kadar uzandığı ifade edilen höyükte; anıtsal yapıların olması, duvarlarında yer alan baskı ve motifler sarayın varlığına işaret ettiği düşünülmektedir. Ayrıca mühür baskılarının kullanılması idari yapıların varlığına, kabartmalar ise iktidarı simgelemektedir. Diğer yandan kazı sonuçlarına göre dini ve kültürel bir merkez olduğu ve aristokrasinin izlerinin bulunduğu ortaya çıarılmıştır. Buradan yola çıkarak merkezi bir otoritenin varlığı ve bu otoritenin bürokratik yapısının kurgulandığı düşünülmektedir. Bu bağlamda bürokrasiye ait ilk izler araştırıldığında, Arslantepe'nin de ilk örnekler arasında olması gerektiği ileri sürülmektedir. 


\section{3. Çalışmanın Önemi}

Bürokrasi çalışmalarına bakıldığında bürokrasiyi genel olarak geleneksel ve modern olarak ayırabilmek mümkündür. Modern anlamda bürokrasi, 18. yüzyılda ilk kez Vincent de Gournay tarafından kullanılmış, Max Weber tarafından 20. Yüzyılın başlarında bir örgüt modeli olarak ifade edilmiştir. Ancak bürokrasi kavramının geleneksel olarak kavramsallaşması daha eski tarihlere dayanmaktadır. Özellikle Eski Çin ve Mısır medeniyetlerinde bazı uygulamaların bürokratik yapıların gelişmesine olanak sağladığı ve ilk örnek oluşturduğu bilinmektedir (Gültepe, 2019: 23-25). Bu bağlamda tarihsel açıdan bakıldığında Malatya Arslantepe Höyüğünde yapılan çalışmalarda, Kalkolitik Dönem'e kadar uzanan ${ }^{1}$ bir tarihsel geçmişte, yerleşim yeri ve saray alanında ekonomik ve sosyal alanların var olduğu ortaya çıkmıştır. Arslantepe'nin yerleşim merkezi, devlet ve bürokrasi ile olan ilişkisini ele alınan çalışmalar bizzat kazı çalışmalarında yer alan arkeologlar tarafından yapılmıştır. Kazı heyetinden bilim insanları, birçok çalışmada erken devlet, bürokratik yapılar, muhasebe fonksiyonları, saray ve seçkin sınıf üzerinde durmakta ve genel olarak birlikte ele almaktadır. Ancak bu çalışmada bürokrasi kavramından hareketle analizler yapılmış ve geleneksel bürokrasi örnekleri arasında olması gerektiği savunulmuştur. Çalışmanın özelde Malatya, Anadolu, Türkiye genelde ise bürokrasi literatürüne katkı sağlaması hedeflenmektedir.

\section{4. Çalışmanın Sınırlılıkları}

Çalışmada Malatya ilinde yer alan Arslantepe Höyüğünde yapılan kazı çalışmalarının sonucunda ortaya çıkan bürokratik bulgular ile sınırlandırılmaktadır. Yerleşim yerindeki devlet benzeri bir yapılanma olduğu arkeolojik çalışma sonuçlarına dayanarak ifade edilmektedir. Ayrıca Malatya'daki ilgili birçok kamu kurumu ve yöneticisi başlangıcı ile ilgili farklı tarihler verse de ortak bir kanaat ile tarihi devlet yapılanmalarına ilk olduğunu beyan etmektedir. Bu noktada kazı ekibinin bilimsel çalışmalarının yanı sıra Malatya Valiliği "Arslantepe-Malatya" ve Battalgazi Belediyesi "İlk Devlet Arslantepe (5000 Yıllık Tarih)" başlıklı kitapçıklar yayımlamıştır. Bu eserlerde kavramsal olarak "devlet” vurgulanmıştır. Özet olarak çalışmada, Arslantepe'de siyasi ve idari yapılar ile sınırlandırılmakta ve bürokrasinin ilk izleri araştırılmaktadır.

\subsection{Araştırma Soruları}

S.1. Devlet ve saray gibi kavramların oluştuğu yerlerde geleneksel bürokrasi yapılarının da beraberinde ortaya çıktığı söylenebilir. Bu bağlamda Arslantepe'de kazılar sonucunda ortaya çıkan bulgular; yerleşim yeri, ekonomik ve idari yapılanmaları gösterirken, bürokrasiye vurgu yapılmış mıdır?

S.2. Kazı çalışmasında bulunan duvar bezemeleri, kabartmaları ve mühürlemeleri siyasal alandaki karşılığı ne olabilir?

S.3. "Geleneksel Bürokrasi” literatürü incelendiğinde, ilk bürokrasi izlerinin Eski Çin (M.Ö. 2000’li y1llar) ve Eski Mısır (M.Ö. 4000-2000) medeniyetlerinde ortaya çıktığı ifade edilmektedir. Oysaki Eski Çin ve Mısır'dan daha eski bir tarihe sahip Arslantepe'de, saray, ekonomik ve idari sistem, memurlar, mühürler ve depolar bürokrasinin varlığ 1 için yeterli midir?

\section{Literatür}

$\mathrm{Bu}$ bölümde çalışmanın anahtar kavramı olan geleneksel bürokrasi kavramı ve ortaya çıkışına yönelik literatür özetine yer verilmektedir. Çalışmanın ana konularından olan bürokrasinin ilk ortaya çıkışına dair literatür bilgilerinin yanı sıra bürokrasinin devlet idaresi, şehir yapılanması gibi konulardaki etkisi incelenmektedir.

\footnotetext{
${ }^{1}$ Kazı çalışmaları devam etmekte olup, Neolitik Dönem'e ait izlerin bulunabileceği öngörülmektedir.
} 


\subsection{Bürokrasi}

İlkel toplumlarda aile bağları öne çıkmış ve kabile anlayışı gelişmiştir. İnsanların bir arada yaşama zorunluluğu ve gelişen toplumsal ilişkiler bürokratik yapılara ihtiyaç duyulduğunu göstermiştir. Bu bağlamda ele alındığında, ilkel toplumların klan veya kabile tarzında, kan bağı ile bağlanmış bir yapıda oldukları görülmektedir. Ayrıca ilkel toplumlarda bireyler, geleneksel kurallar ve yerleşik öğretilere göre davranırlardı. Arada herhangi bir aracı kurum veya yaptırım gücü oluşmamıştı. Ancak karşılıklı dayanışmanın ve savunma ilişkilerinin kurulması ve bir otoriteye bağlanması idari yapılara zemin hazırlamıştır (Abadan, 1959: 12). İlk yönetim anlayışının ve bürokratik yapıların ortaya çıkışında, tarım, din, ticaret, nüfusun çoğalması, güvenlik ve savaş gibi etkenler olduğu söylenebilir. Tarihçiler, Çin bürokrasisinin geleneksel anlamda bürokrasinin izlerini taşıdığını ifade ederken, bürokrasinin bu bağlamda gelişmesini dış tehditlere karşı kendilerini koruma güdüleri olduğunu ifade ederler (Eryılmaz, 2017: 88).

Yerleşik hayata geçen medeniyetler arasından Sümerler, ilk medeniyeti Mezopotamya' da kurmuşlardır. “Orta ırmak" anlamına gelen Mezopotamya, uygarlık anlamında dünyaya örnek teşkil etmiştir (Şenel, 1995: 40). Birçok kaynakta, Eski Mısır bürokrasisinin en eski bürokrasi örneği olduğu ifade edilmektedir. M.Ö. 3000'li yıllarda Nil Nehri’nin ulaşım ve sulama gibi teknik ihtiyaçlarda kullanılmasına karar verilmiş (Abadan, 1959: 18) ve büro tarzında ofisler kurulması ile örgütlenme modeli geliştirilmiştir (Başaran, 1989: 45). Mısır piramitleri ve Çin Seddi’nin dönemin şartlarına göre değerlendirildiğinde planlı ve koordineli bir şekilde yapıldığ 1 ve bu eserlerin ancak bürokratik yapılar ile olabileceği düşünülmektedir (Robbins ve Coulter, 2007: 28). Ayrıca Eski Misır ilahlarından kabul edilen Horus'un temsilcisi kral, hem hükümdar hem de ilah sayılırdı. M.Ö. 1198-1167'de kral olan Firavun III. Ramses’in oğlu IV. Ramses'in yazdığı papirüste ${ }^{2}$ kralın $^{\prime}$ bürokrasi vurgusu öne çıkmaktadır (Gültepe, 2019: 23-24):

"Sana toprağının idaresi için Mısır kitabelerinin dehlizlerinde kayıtlı ulu fermanlar yazdım. Yıllık vergilerini yüce hazinene teslim etmek üzere tütsüler taşıyan okçular ve bal toplayıclar tayin ettim. Senin için, halktan gemici ve vergi memurlar ayırdım. Yine senin için kölelerden kanal idaresine bekçiler ve saf arpana gözcüler koydum."

Yukarıdaki notta yer alan kayıtlı ferman, yıllık vergiler, hazine, tayin edilen memurlar, kanal idaresi, bekçiler gibi kavramlar bürokrasinin izlerini ortaya koymaktadır.

Genel olarak toplumların işlerini sistematik olarak koordine eden büyük ölçekli idari görevleri yerine getirmek için tasarlanan organizasyonel yapılara bürokrasi adı verilir. Bürokratik organizasyonun en temel özellikleri uzmanlık, yetki hiyerarşisi ve kurallar sistemidir (Blau, 1956). Ayrıca bilgi ve tecrübelerin günümüze kadar aktarılabilmesine olanak sağlayan yazı, sembol, çizim, figür ve mühürler kesin bir belgelenme anlamına gelmektedir. Bu noktada Eski Çin medeniyetinde yazılı raporlar ve resmi istatistiklerin olması (Albrow, 1970: 16) ilkesel bir idari yapıyı işaret etmektedir. Söz konusu idari yapılar bürokrasinin ilk örnekleri olarak gösterilmişlerdir.

Fransızca bir terim olarak ortaya çıkan bürokrasi; burjuvazi, teknokrasi, aristokrasi gibi sınıfları vurgulayan bir kavram olarak da kabul edilebilir. İlk defa 1745'te Fransız Vincent De Gournay tarafindan kullanılan bürokrasi, "büro" (daire, ofis) ve "krasi” (güç, iktidar) kavramlarının birleşmesinden meydana gelmiştir. Bu bağlamda bürokrasi "büroların iktidarı" anlamına gelmektedir (Kabaklı, 2002: 9). Genel olarak bürokrasi üç farklı anlam ile karşımıza çıkar. Bunlar; kırtasiyecilik, devlet idaresi ile belirli ilkeleri olan yönetim ve kurumsallaşma şeklidir (Çevikbaş, 2014: 75). Bu yüzden devlet ve bürokrasi kavramları birçok zaman birlikte kullanılmaktadır. Bürokrasi, devlet kavramının şekillenmesinde ve kurumsallaşabilmesinde etkili olan bir araç olarak görülür. Bu bağlamda geleneksel devlet yapılanmalarından modern devlete uzanan tarihsel süreç genel olarak beş grupta incelenebilir. Bunlar geleneksel yapılı, feodal yapılı, geç feodal dönem, mutlakiyetçi, modern ulus-devlet olarak ele alınabilir (Öztürk, 2017: 18-19). Söz konusu dönemlerde devletin yapılanması ve uygulama şekli farklılık gösterse de bürokrasinin varlı̆̆ı değişmemiştir.

Modern bürokratik yapılar rasyonel örgüt tiplerinden oluşmaktadır. Weber'e göre; bir örgütte veya kurumsal yapıda işbölümü, uzmanlaşma, gayrişahsilik, otorite, hiyerarşik yapı, yasalarla düzenlenen yetki alanı ve teknik nitelikte kariyer sistemi var ise burada rasyonellikten bahsedilir. Söz konusu özelliklerin devlet

\footnotetext{
${ }^{2}$ Eski Mısırlıların papirüs saplarından yaptığı kâğıt.
} 


\section{F.Ü. Sosyal Bilimler Dergisi 2021-31/2}

dairelerinde, özel işletmelerde ve sivil toplum kuruluşlarında egemen hale gelmesiyle bürokratikleşme tamamlanmış olur (Eryılmaz, 2017: 87). Bir başka açıdan ise teknolojide yenilikler ve sanayileşmenin ortaya çıkması kurumsal yapılardaki bürokrasiler için "modern bürokrasiler" kavramı kullanılmaktadır. Söz konusu yapıların ortaya çıkmasında ekonomik yapı, kapitalist sistem ve kurumsal yapılardaki değişiklikler yer almaktadır (Dursun, 1992: 134). Bununla birlikte tarihte bazı durumlar bürokrasinin siyasi mücadeleler sonucu oluştuğunu da gösterebilmektedir. Mevki ve görev dağılımını siyasal bir kaynak olarak kabul eden yöneticilerin, memur sınıfı oluşturma çabası bu duruma örnektir (Dreyfus, 2014: 23). 18. yüzyıl sonrasında modern devletlerde bu durum açıkça görülmektedir.

Weber'in patriyarkal ve patrimonyal bürokrasi adını verdiği ve gelenekseli ifade eden otorite tipleri hükümdarın önderliğinde, onun normlarına göre, aile yönetimi şeklinde hareket etme anlamlarını içermektedir (Weber, 1993: 253). Ayrıca belirli bir grup üzerinde hakimiyeti bulunan ve grubun en yaşlı üyesinin egemenliğin sahibi olarak görmektedir. Bu durum geleneksel yapıda gerentokrasi terimi ile ifade edilir (Weber, 2017: 69). Rasyonel olmayan ve bürokratik yapılanma olarak görülen geleneksel otoriteler, tarihteki ilk idari örgütlenme modelleri arasında gösterilir. Dünyanın birçok yerinde farklı şekillerde görülen bu yapılar, toplulukların bir hükümdar veya feodal yapı etrafında yaşam sürmesine yardımcı olmuştur.

Mises’a göre, hükümeti icra eden kamu yönetimlerinin şekilsel ve bürokratik bir yapıda olması gerekmektedir. Kırtasiyecilik gibi olumsuz itibarları olmasına rağmen bürokrasi kurumsal yapıların temel yapı taşıdır. Mises'a göre, kamu kurumlarının varlığı korunmalıdır (Mises, 2018: 155). Ancak bürokrasinin sağlıklı oluşması ve gelişmesinde liyakat esas olmalıdır. İşinin ehli olan devlet hizmetlerini yerine getiren bir yönetici grubun oluşması nepotizmden uzaklaşmayı beraberinde getirmektedir. Yakınlarını kollayan ve yönetimde liyakati savunmayan yapılarda bürokrasilerin sağlıklı gelişmesi olanaksızdır (Lipset, 1986: 49).

Eleştirel bir yaklaşımla bürokrasi, sermaye sınıfının bir aracıdır ve sınıfsız bir toplumla yok olabilir. Ona göre bürokratik yapılar sömürü düzeninin eserleridir (Mouzelis, 2001: 23). Bu bakımdan modern bürokrasinin mutlakiyetçi monarşik yapıların sona ermesiyle oluştuğunu iddia eden Marksist görüşe göre, sınıflı toplumlarda bürokrasi ve bürokratikleşme kaçınılmazdır.

\section{Bulgular}

Malatya Arslantepe'de ilk sistematik kazı çalışmaları Fransız arkeolog Louis Delaporte tarafindan 1932 yılında başlamıştır. 1946'da başka bir Fransız arkeolog Claude Schaeffer devralmışıı. 1961 yllında ise İtalyan arkeologlarca tekrar başlatılan kazılar, 1990 yllından itibaren Roma La Sapienza Üniversitesi Arkeoloji Bölümü öğretim üyesi Prof. Dr. Marcella Frangipane başkanlığında sürdürülmüş̧ür. Marcella Frangipane'nin emekliye ayrılmasından sonra Arslantepe Höyüğü Kazı Heyeti Başkanı Doç. Dr. Francesca Balossi Restelli olmuştur ve çalışmalar devam etmektedir. 


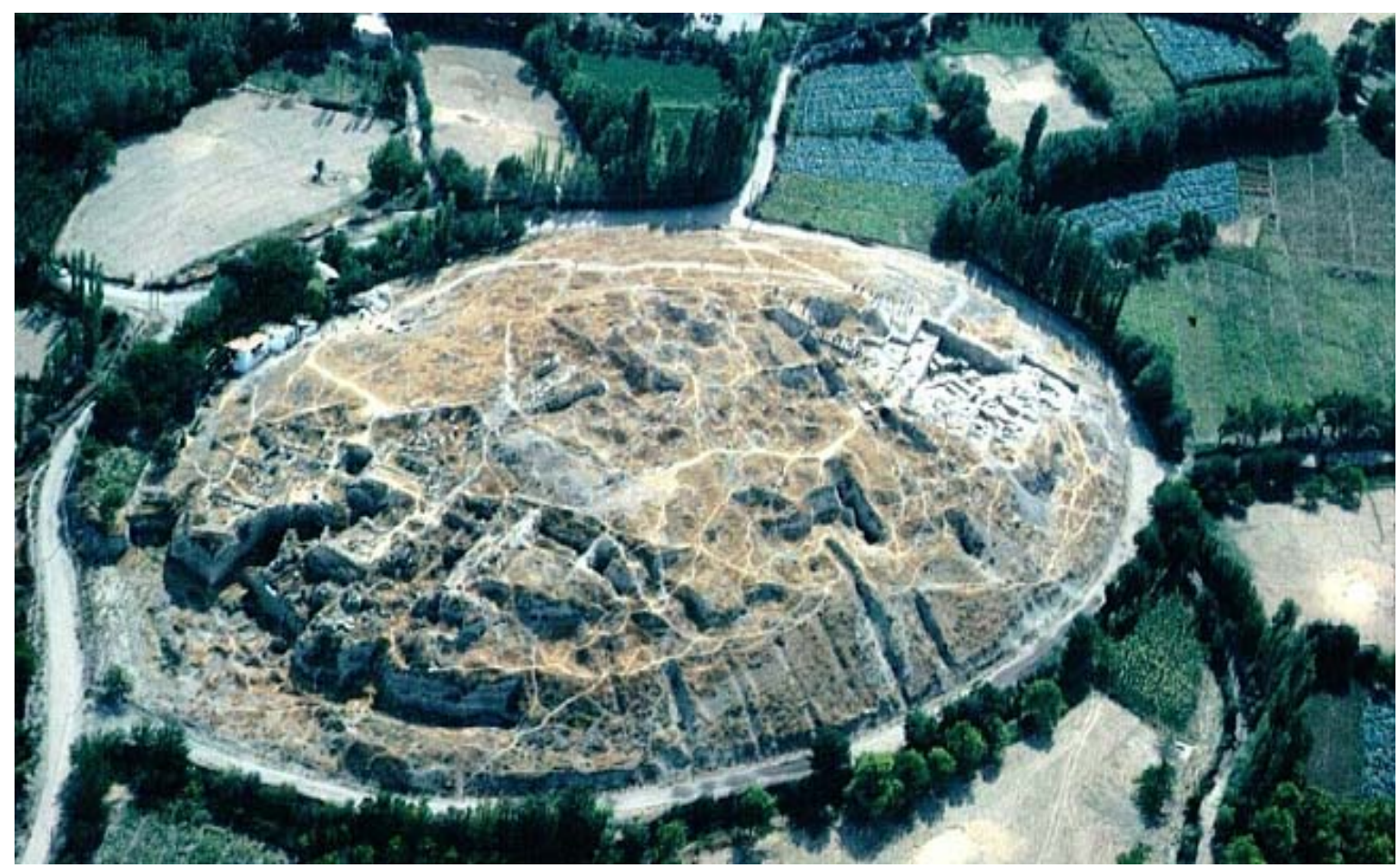

Şekil 1: Arslantepe Höyüğü (Frangipane, 2011: 134).

Şekil 1'deki fotoğrafta Malatya ili Battalgazi ilçesinde yer alan Arslantepe Höyüğü'nün kuşbakışı görüntüsü yer almaktadır. Malatya'nın kuzeydoğusunda il merkezine $7 \mathrm{~km}$ uzaklıkta yer alan höyük Sadece Malatya için değil Anadolu topraklarında ortaya çıkarılmış önemli bir arkeolojik yerleşimdir. Arslantepe'de yapılan çalışmalarda elde edinilen bulgulara göre M.Ö 4500'lü yıllarda "Geç Kalkolitik 1-2" diye adlandırılan dönemde, Mezopotamya'nın farklı kültürleri bölgede yer almıştır. Tablo 1'de kronolojik, dönemsel ve kültürel bilgiler derlenmiştir. Söz konusu tablodan anlaşılacağı üzere Arslantepe tarihin farklı dönemlerinde birçok medeniyete ev sahipliği yapmıştır. Böylesine tarihi birikimi olan bir yapıda idari ve ekonomik işlerin yoğun olduğu tahmin edilebilir.

Tapınak, saray, metal ve seramik ürünler ile birlikte çok sayıda mührün bulunması söz konusu yerleşim yerinde idari ve ekonomik anlamda sistemli bir yapı bulunduğuna işaret etmektedir. Arslantepe'de Geç Uruk döneminde başladığı düşünülen merkezileşme, dördüncü milenyumun sonlarında, Mezopotamya tarzında ekonomik ve idari sistemi işaret eden bu Anadolu toplumunun erken devlet oluşumunu göstermektedir (Frangipane, 1997b: 56).

Arslantepe'de idari sistemin varlığı, koridorun batı duvarından açılan ve depoların karşısındaki bir oyukta bulunan binlerce mührün (Şekil 4 ve 6) geri kazanılmasıyla kanıtlanmaktadır. Yaklaşık 120 farklı mühür izlenimi taşıyan ve depo kapıları içerisindeki farklı kaplara yapıştııılan mühürler, gruplandırılarak kesin bir sıraya göre kullanılmıştır. Bu şekilde bir gruplandırma, farklı depo tarzlarına dayalı olabilir. Bu mühürler ancak karmaşık bir idari sistemin ve kayıt işlemlerinin varlı̆ğına işaret edebilir (Frangipane, 1997b: 51).

Tablo 1: Arslantepe'de Kronolojik Dönem ve Kültürler (Frangipane, 2019: 73)

Genel Kronoloji $\quad$ Dönemi $\quad$ Tarih Aralığı $\quad$ Çă̆daş Yakın Doğu Kültürleri

MS 400 - 
Demir Çağı

Geç Bronz II

Geç Bronz 1

Orta Tunç Çağ1

Erken Bronz III

Erken Bronz II

Erken Bronz 1

Geç Kalkolitik 5

Geç Kalkolitik 3-4

Geç Kalkolitik 1-2
II-III

IV

VB

VA

VI D

VI C

VI B1-VI B2

VIA

VII

VIII
MÖ 1200-700

MÖ 1500-1200

MÖ 1750-1500

MÖ 2000-1750

MÖ 2500-2000

MÖ 2750-2500

MÖ 3200-2800

MÖ 3400-3200

Mezopotamya'da Geç Uruk kültürü

MÖ 3900-3400

Mezopotamya'da Erken ve Orta Uruk kültürleri

Yeni Hitit hükümdarlığı, Yeni Asur imparatorluğu, Urartu hükümdarlığı

Hitit İmparatorluğu

Eski Hitit Krallığ

Orta Anadolu'daki eski Asur kolonileri

Erken Hanedan 111 b, Akad imparatorluğu, Mezopotamya'da 3. Ur Hanedanı

Mezopotamya'da Erken Hanedan 11-III a

Jemdet Nasr ve Mezopotamya'da Erken Hanedan I

MÖ 4500-3900 Mezopotamya'da Ubeyd sonrası kültürler

Arkeolojik çalışmalarla Şekil 2'deki alanda zaman içerisinde değişikliğe uğramış kamu yapılarının külliye tarzı bir yapı meydana getirdiği kanıtlanmıştır. Birden fazla amaç için, özellikle dini, ekonomik ve yönetsel olmak üzere inşa edildiği düşünülen üç külliyeden oluşmaktadır. Söz konusu yapı genişlik ve büyüklük anlamında öne çıkar ve tapınak veya saray külliyesinin ilk örneğidir (Frangipane, 2002: 270). Tarihe 1şık tutan arkeolojik kazılar Arslantepe Höyüğü'nün; sosyal, ekonomik, siyasal ve askeri merkez olduğunu açıkça ortaya koymaktadır. Bu bağlamda farklı alanlarda olan yapıların birlikte idaresi için bürokratik, planlı ve sistematik bir şekilde yapılanma olduğu düşünülmektedir (Şekil 3)..

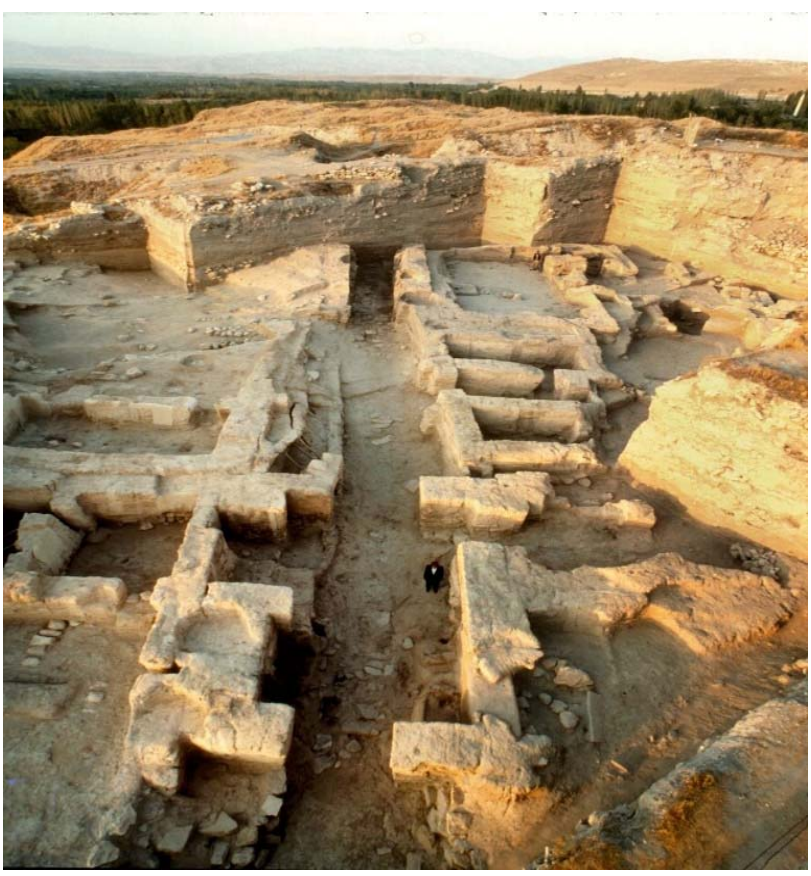

801 
Şekil 2: Arslantepe Höyüğü Saray Yapılanması (Frangipane, 2011: 137).

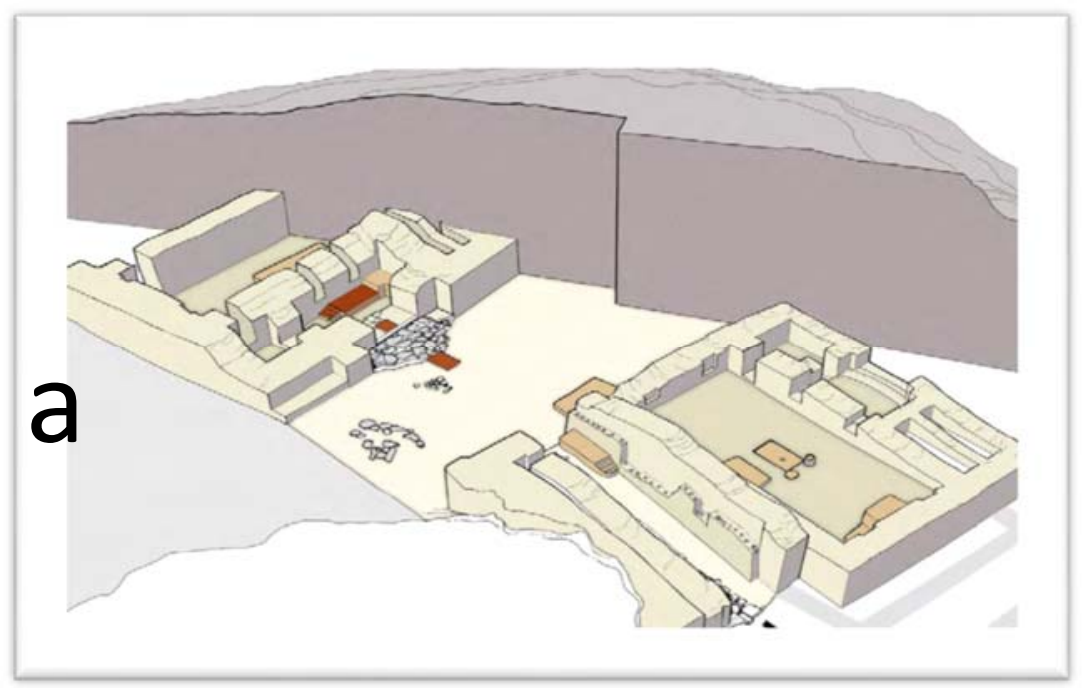

Şekil 3: Saraya Ait Üç Boyutlu Çizim (Frangipane, 2018: 80).

Şekil 3'de saray yapılanmasının erken dönemine ait üç boyutlu çizimi yer almaktadır. Daha önceki tapınaklara göre çok yüksek, anıtsal ve heybetli bir binada kamusal alan oluşmuştur. Damgalı baklava motifleri ve duvar resimleri ile süslenmiş bir giriş koridoru, ziyaretçilerin kendilerini anıtsal ihtişamlı bir binanın karşısında bulacakları çok büyük bir avluya açılmaktadır. Yüksek bir platform ve üç basamağın üzerinde kömürleşmiş ardıç ağacının kalıntılarının bulunması, taşınabilen, muhtemelen sandalye veya taht olduğu varsayılan alanda halkı selamlama veya halka sesleniş anlamına gelen kamu ile temas noktasıdır. Figür incelendiğinde halkın saray içlerine giremediği görülmektedir. Şekil 3'de "a" ile belirtilen alanın, liderin kabul binası olduğu düşünülmektedir (Frangipane, 2018: 79). Vatandaşların evleri daha çok yerleşim alanı yamaçlarında yapılmıştır. Halkın höyük etrafındaki ovada yaşadığı tahmin edilmektedir (Di Nocera 2008). Bu durum ise toplumun saraydan bizzat yönetildiğine işaret etmektedir. Böylelikle iktidar yöneten olurken, toplum yönetilen olmakta ve geleneksel bürokrasi anlayışında yöneten ve yönetilen kavramları ortaya çıkmaktadır. Bu bağlamda toplum ile iktidar arasında hiyerarşik bir yapının oluştuğunu söylenebilir.

Höyük’te idari işlerin olduğuna dair kanıtlar vardır. Her türlü mal ve malzemenin depolanması, bunların yeniden dağıtımı konusunda hazırlanan mühürler ve cretulalar ${ }^{3}$ küplerle birlikte (Şekil 4, h ve i) bulunmuştur. Burada ki bulguların önemli bir noktası ise, depo tarzı yapıların iki farklı büyüklükte olmasıdır. Muhtemelen

\footnotetext{
${ }^{3}$ İlk irsaliye olarak Cretula adı verilen, kapların üzerine konulan, kaptaki malın cinsini ve miktarını belirten kil kullanılmıştır. Cretula malın cinsini ve miktarını gösteren simgeler içermektedir (Yükçü ve Atağan, 2011).
} 
ilkinde depolama diğerinde dağıtım işlemi yapılmaktadır (Frangipane, 2002: 275).
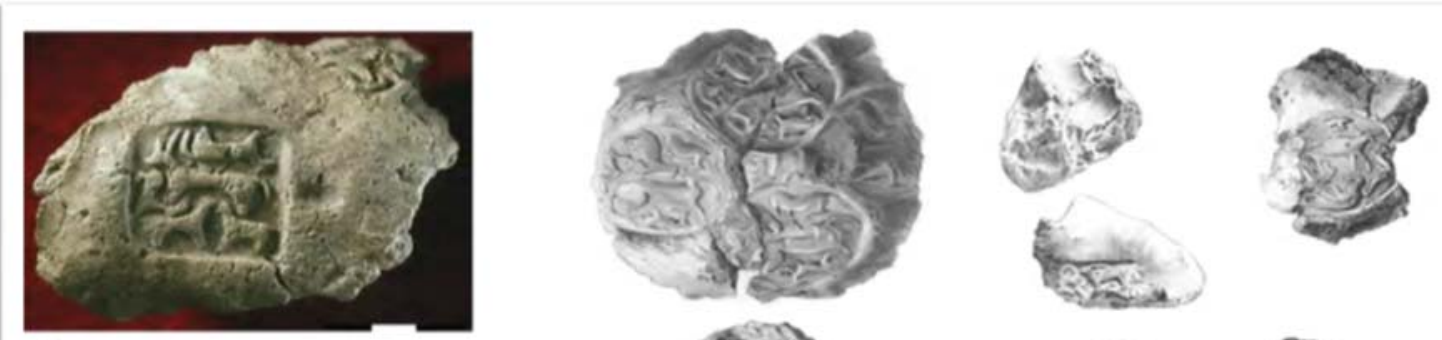

a
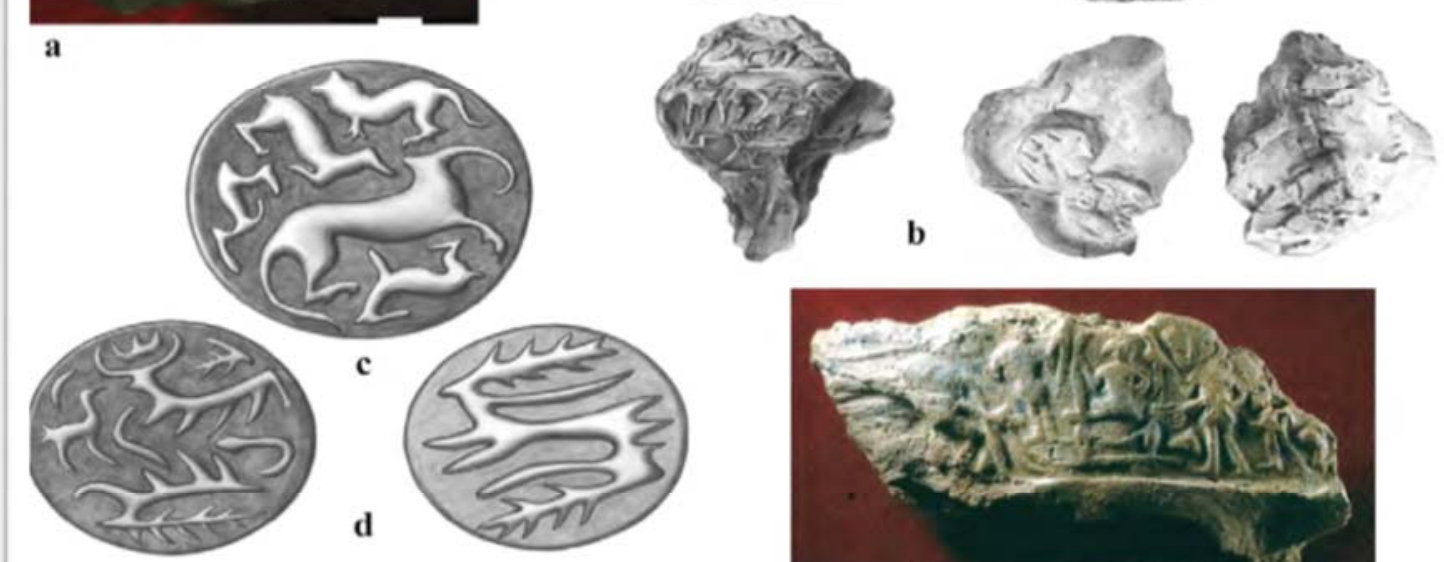

d
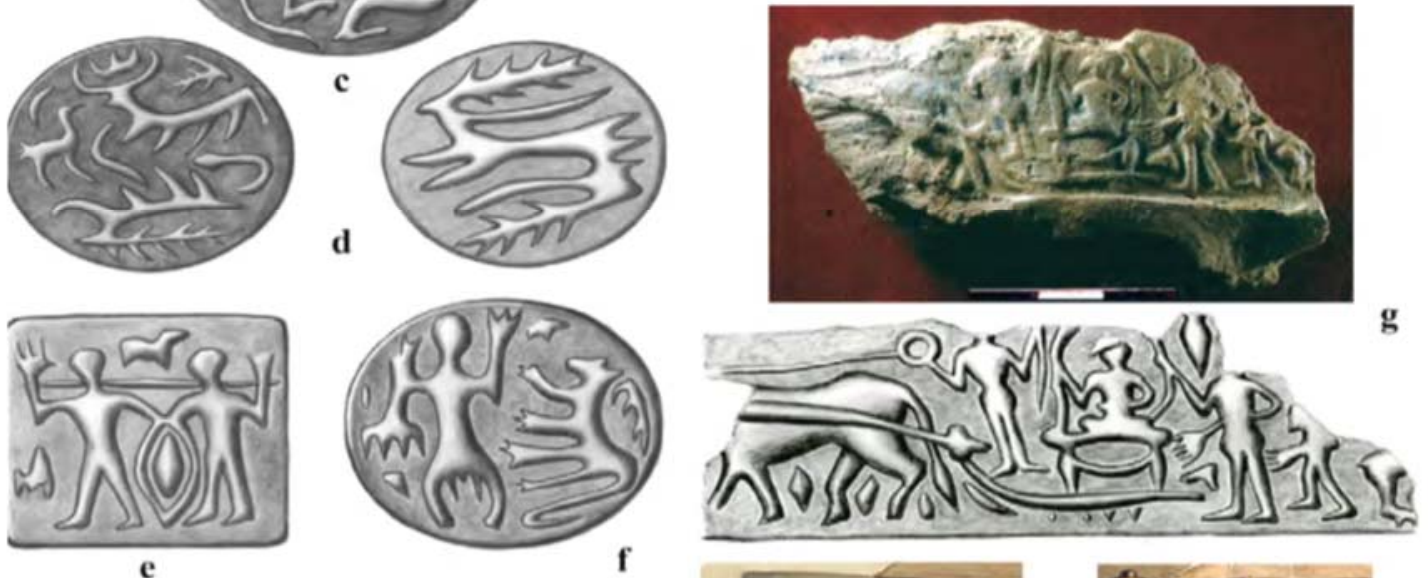

f
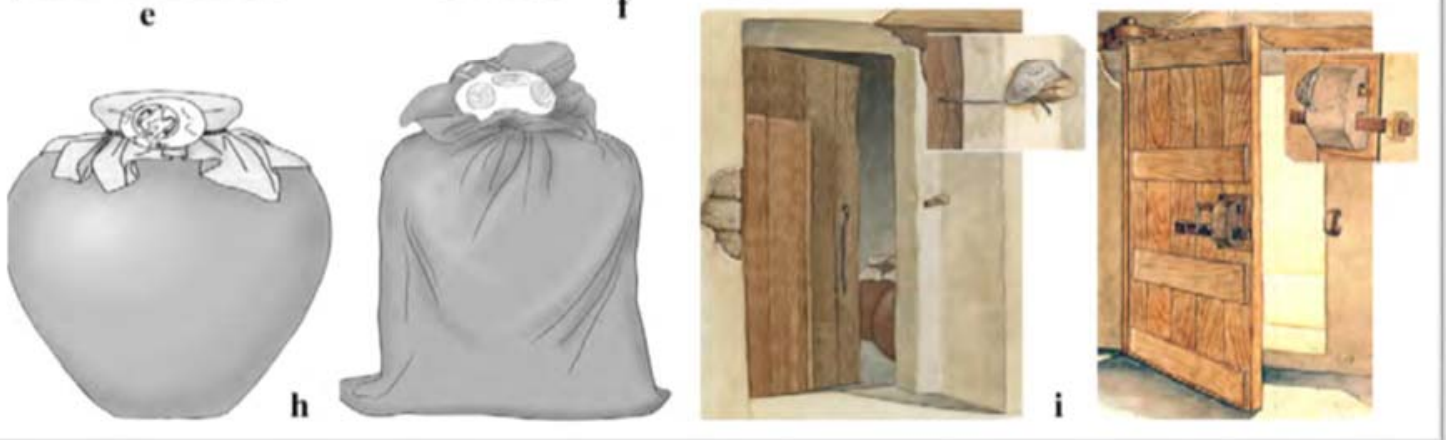

Şekil 4: Höyükte Bulunan Mühürler ve Çizimleri (Frangipane, 2018: 84).

Çok sayıda mühür, kabartma (Şekil 6) ve duvar bezemelerinin olması saray işlerinin belirli kurallarca yapıldığını ve idari işlerin varlığını göstermektedir. Bulunan iki binden fazla öğe (mühür, cretula vb.) depolama ve muhasebe sisteminin güçlü olduğuna işarettir (Frangipane: 2012: 34). Depolamanın ve dağıtımın farklı alanlarda yapılması, yerleşim yerinde bir tür uzmanlık ve işbölümü anlayışının izlerine işaret edebilir. Ayrıca dağıtımın belirli mühürler ile yapılması dağıtan memurların olduğunu göstermektedir. Muhtemelen memurlar, üst otoriteden aldığı yetki ile hareket etmekte ve yaşamın sürdürülebilmesi için işbölümü yapmaktadır. Bu kararların belirli usül ve kaidelere göre yapıldığı düşünülmektedir. Ayrıca iki yüzden fazla mühürde tarım ve hayvancılığı simgeleyen figürler (Şekil 4, a-g) bulunmaktadır. Bu bulgunun ise toplumun geçim kaynakları ile ilgili bilgiler taşıdığı düşünülebilir. $\mathrm{Bu}$ figürlerin kendi içinde bir sistematik içerisinde olduğu söylenebilir. 


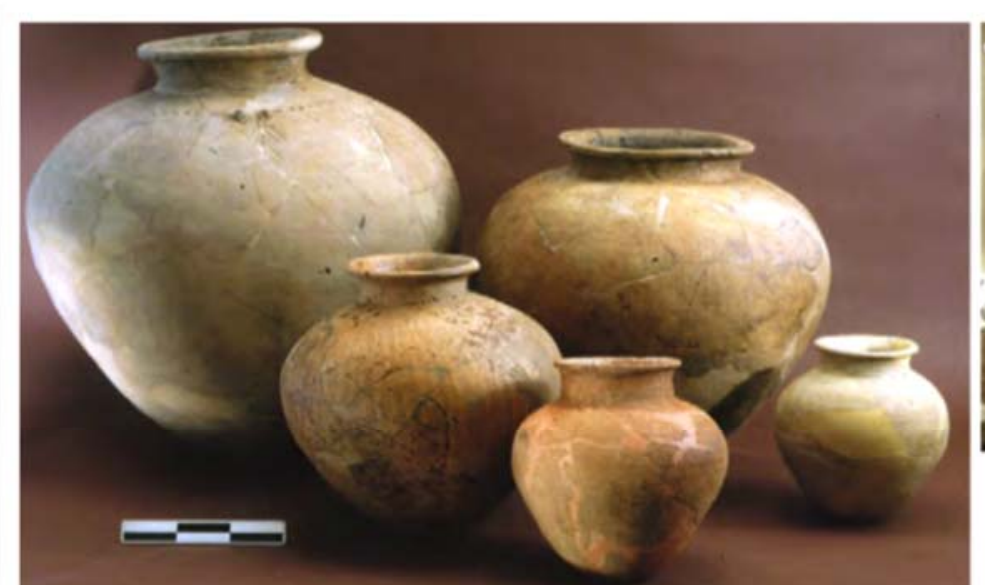

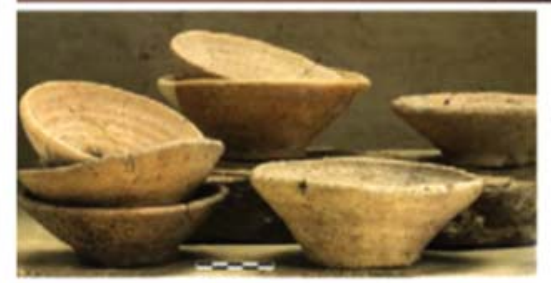

c
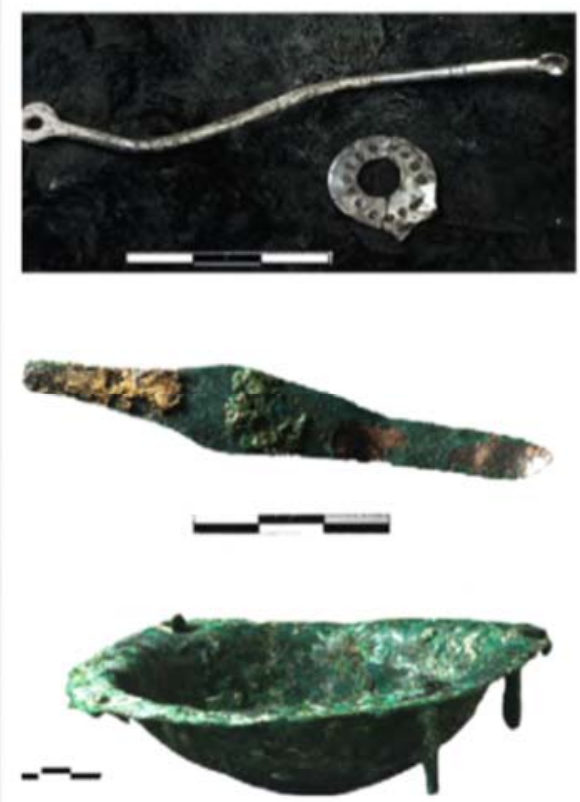

a

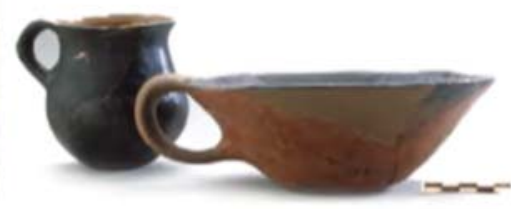

d

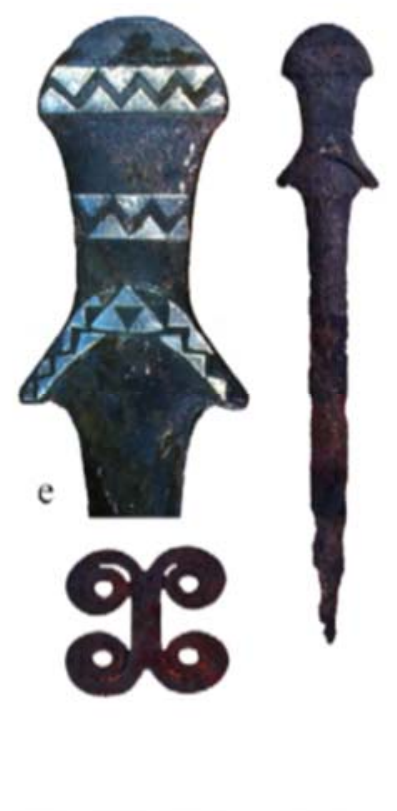

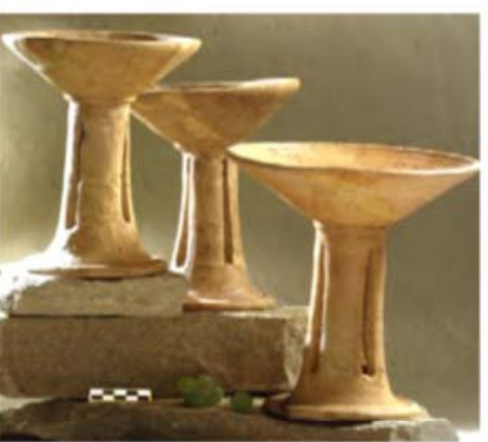

b
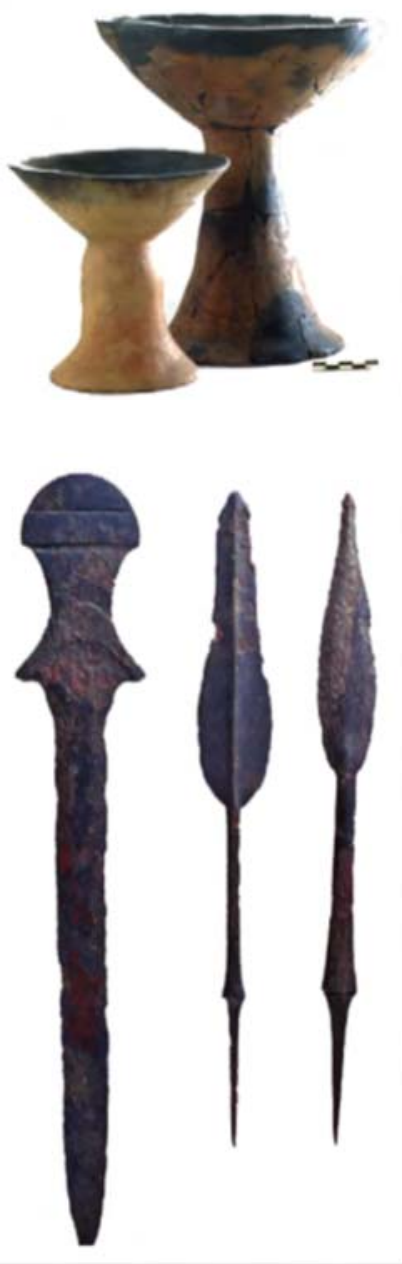

Şekil 5: Arslantepe'de Seramik ve Metal Objeler (Frangipane, 2018: 86).

Arslantepe'de çok özenli bir şekilde metal ürünlerin imal edildiği ve farklı türde metaller kullanıldığı görülmüştür. Bakır, kurşun, altın, gümüş ve metal alaşımlı öğeler dönemin madenciliği hakkında önemli fikirler vermektedir. En önemli metal öğeler arasında mızrak uçları ve kılıçlar yer almaktadır (Şekil 5). Her biri farklı metal ve büyüklükte olan öğeler muhtemelen şef veya rütbeli kişilerin saygınlığı ile doğru orantılı olarak imal edilmiştir (Frangipane, 2018: 97). Bu durum askeri hiyerarşinin varlığına işaret etmektedir. Bir başka açıdan yüksek statülü bir kişinin mezarı (Kral mezarı) taş sanduka içinde bulunmuştur. Burada ise metal nesne, silah ve mücevher gibi farklı semboller bulunması siyasi ve askeri hiyerarşik yapıyı çağrıştırmakta ve lidere, komutana verilen önemi ifade etmektedir. Liderin gücü ve otoritesinin vurgulanması ve hiyerarşik bir yapının oluşması geleneksel bürokrasinin izlerine işaret etmektedir. 

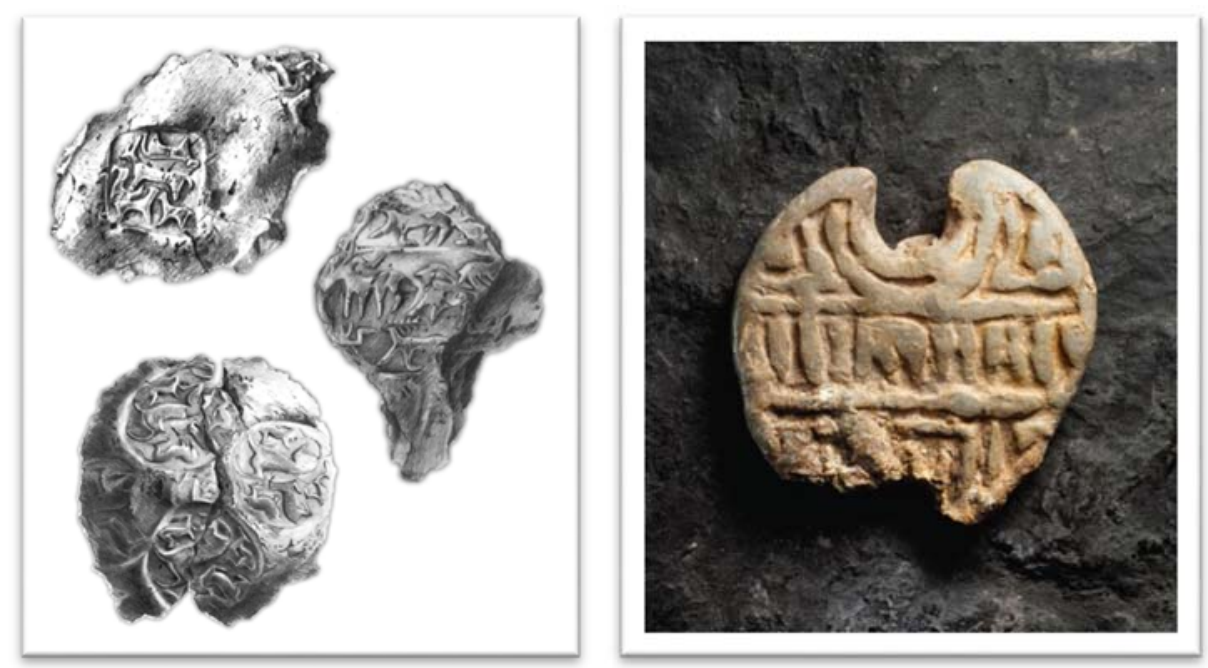

Şekil 6: Mühür ve Kabartmalar (Atlas, 2015).

Arslantepe'de kral veya liderin ihtişamlı bir iktidar alanı olduğu söylenebilir. Söz konusu iktidarın tepenin en üst noktasında saray yapılanmasında olduğu düşünülmektedir. Ayrıca devredilmiş yetkilere sahip bir memur sınıfı olarak bürokrasinin ortaya çıkışı, Astantepe'de erken devlet ve bürokrasi adına önemli bir bulgudur (Frangipane, 2018: 10). İktidar veya güç bağlamında duvar resimlerinin binaya erişim alanları boyunca en belirgin yerlere yerleştirmesi, korundukları resimlerin saf ve basit süslemeler olmadığını, bu resim veya çizimlerin önemli figüratif motifleri temsil ettiği düşünülmektedir. Sembolik içeriği nedeniyle ziyaretçiye ideolojik mesajlar da vermektedir. Saray kompleksinin iki bölgesinde (mağazalara ve iç avluya erişim odası ve koridorun en kuzey bölümü) olağanüstü iyi korunmuş figürler, son aşamada yok edilmiştir (Frangipane, 1997a: 64).

\section{Sonuç ve Değerlendirme}

Devlet ve saray gibi kavramların oluştuğu yerlerde geleneksel bürokrasi yapılarının da beraberinde ortaya çıktığı söylenebilir. Bu bağlamda Arslantepe'de kazılar sonucunda ortaya çıkan "erken devlet", "merkezi yerleşim" ve "saray" bulguları, bu alanda bürokratik yapıların olabileceğini göstermektedir. Kazı çalışmasında bulunan duvar bezemeleri, kabartmaları ve mühürlemeleri, iktidar ve otorite vurgusu içerir ve bu alanda sistematik bir yapı ile yani bürokrasi kavramıla ifade edilebilir.

Günümüze kadar yapılan çalışmalarda ortaya çıkan sonuçlara göre; Arslantepe M.Ö. 6000'li yıllara kadar uzanan tarihi ile bilinen en eski yerleşim yerlerinden biri olmuştur. Bulgular "Erken Devlet" olduğunu kanıtlar niteliktedir. Ayrıca gerçek bir kentleşmenin olmadığı düşünülen kazılarda saray, idari yapı, ekonomik ve askeri sistemler merkezi bir devlet öngörüsünü desteklemektedir. Bu bağlamda Arslantepe'de siyasi, idari, ekonomik ve askeri açıdan bürokrasinin oluştuğu söylenebilir.

“Geleneksel Bürokrasi” literatürü incelendiğinde, Eski Çin (M.Ö. 2000’li yıllar) ve Eski Mısır (M.Ö. 40002000) medeniyetleri ilk örnekler olarak gösterilmektedir. Ancak tarihsel sinıflandırma yapıldığında Arslantepe'nin daha eski bir tarihte oluştuğu görülmektedir. Ayrıca arkeolojik bulgulara göre siyasi, idari, ekonomik ve askeri yapılanmanın geleneksel bürokrasiye uygun olduğu da kanıtlanmıştır. Bu bağlamda Arslantepe'nin, geleneksel bürokrasinin ilk örneklerinden biri olduğu ve ilk bürokrasi örnekleri arasında Eski Çin ve Mısır'dan önce yer alması gerektiği düşünülmektedir. 


\section{Kaynakça}

Abadan, N. (1959). Bürokrasi. Ankara: A.Ü. S.B.F Yayınları.

Albrow, M. (1970). Bureaucracy. London: Pall Mall Press.

Atlas (2015). Arslantepe: Devletin kökeni. Atlas Dergisi. Erişim adresi: https://www.atlasdergisi.com/kesfet/arkeoloji-haberleri/4536.html

Başaran İ. E. (1989). Yönetim. Ankara: Gül Yayınevi.

Blau, P. M. (1956). Bureaucracy in modern society. Crown Publishing Group/Random House.

Çevikbaş, R. (2014). Bürokrasi kuramı ve yönetsel işlevi. Ekonomi ve Yönetim Araştırmaları Dergisi, 3(2), 75-102.

Di Nocera, G. M. (2010). Metals and metallurgy. Their place in the Arslantepe society between the end of Food and urbanization. Material and textual perspectives on alimentary practice in early Mesopotamia the 4th and the beginning of the 3rd millennium BC. Economic Centralisation in Formative States. The Archaeological Reconstruction of the Economic System in 4th Millennium Arslantepe, (3), 255-330.

Dreyfus, F. (2014). Bürokrasinin icadl. İstanbul: İletişim Yayınları.

Dursun, D. (1992). Bürokrasi teorisi ve yönetim. Sosyal Siyaset Konferansları Dergisi, (37-38), 133-149.

Eryılmaz, B. (2017). Bürokrasi ve siyaset. (Altıncı Baskı) İstanbul: Alfa Yayınları.

Frangipane, M. (1997a). A 4th-millennium temple/palace complex at Arslantepe-Malatya. North-South relations and the formation of early state societies in the northern regions of Greater Mesopotamia. Paléorient, 45-73.

Frangipane, M. (1997b). Arslantepe-Malatya. In Emergence and change in early urban societies (43-58). Springer, Boston, MA.

Frangipane M. (2002). Yakındoğuda devletin doğuşu. (Çev: Z. Zühre İlkgelen) İstanbul: Kanaat Yayınları.

Frangipane, M. (2011). Arkeoatlas: Tarihöncesinden Demirçağı'na Anadolu'nun Arkeoloji Atlası, (Ed. N.Karul), Doğu Anadolu, 126-137.

Frangipane, M. (2012). Fourth millennium Arslantepe: The development of a centralised society without urbanisation. Origini, 34, 19-40.

Frangipane, M. (2018). Different trajectories in state formation in Greater Mesopotamia: A view from Arslantepe (Turkey). Journal of Archaeological Research, 26(1), 3-63.

Frangipane, M., 2019. “Arslantepe. Siyasi Merkezin Yükselişi ve Düşüşü: Tapınaktan Saraya Saraydan Surla Çevrili Bir Kente / Arslantepe. The rise and development of a political centre: From temple to palace to a fortified citadel". I. Uluslararasi Arslantepe Arkeoloji Sempozyumu / I. International Arslantepe Archaeology Symposium, 4-6 October 2018 Malatya, 71-104.

Frangipane, M., \& Palmieri, A. (1983). A protourban centre of the late Uruk period in perspectives on protourbanization in Eastern Anatolia: Arslantepe (Malatya). An interim report on 1975-1983 campaigns. Origini. Rivista di Prehistoria e Protostoria delle Civiltà Antiche, 12(2), 287-45

Gültepe, N. (2019). Mührün gücü, ilk Türk Islam devletlerinde ve Osmanlllarda Bürokrasi. İstanbul: Kap1 Yayınları.

Kabaklı, A. (2002). Millete vurulan canlı pranga. İstanbul: Türk Edebiyatı Vakfı Yayınları.

Lipset, S. M. (1986). Siyasal insan (Çev: Mete Tunçay). Ankara: Teori Yayınları.

Mises, L. V. (2018). Bürokrasi. (Çev: Atilla Yayla ve Feridun Ergin) İstanbul: Liberte Yayınları.

Mouzelis, N. P. (2001), Örgüt ve bürokrasi, (Çev: Alın, H. Bahadır), Konya: Çizgi Kitabevi.

Neuman, W .L., (2006), Toplumsal araştırma yöntemleri nitel ve nicel yaklaşımlar Cilt 2, (Çev: Sedef Özge). İstanbul: Yayınodası.

Öztürk, N. K. (2017). Bürokrasi-siyaset ilişkileri ve Türkiye. Ankara: Siyasal Yayınevi.

Robbins, S. P., Coulter M. (2007). Management, 9th. Edt. New Jersey, USA: Prentice Hall.

Şenel, A. (1995). Siyasal düşünceler tarihi. Ankara: Bilim ve Sanat Yayınları.

Weber, M. (1993). Sosyoloji yazıları. (Çev: Taha Parla). İstanbul: Hürriyet Vakfi Yayınları.

Weber, M. (2017). Bürokrasi ve otorite. ( Çev: H. Bahadır Akın). 8. Baskı. İstanbul: Adres Yayınları.

Yükçü, S, Atağan, G. (2011). Ortadoğu'da zaman tünelinde ticaret. Muhasebe ve Finans Tarihi Araştırmaları Dergisi , (1) , 86-109. 